\title{
Changes in the serum cartilage biomarker levels of healthy adults in response to an uphill walk
}

Dumnoensun Pruksakorn ${ }^{1}$, MD, PhD, Premchai Tirankgura ${ }^{1}, \mathrm{MD}$, Sirichai Luevitoonvechkij ${ }^{1}$, MD, Samatchai Chamnongkich ${ }^{2}$, PhD, Nantawit Sugandhavesa ${ }^{1}$, MD, Taninnit Leerapun ${ }^{1}$, MD, Peraphan Pothacharoen ${ }^{3}$, PhD

INTRODUCTION To prevent long-term unfavourable consequences to the articular cartilage of weight-bearing joints, serum biomarkers can be used to identify optimum loading of activities. This study aimed to investigate the circulation pattern of serum cartilage biomarkers in healthy adults in response to an uphill walk.

METHODS This study recruited 58 healthy participants for the experimental group and 24 matched participants for the control group. Participants in the experimental group walked continuously for $14 \mathrm{~km}$ on a pathway with a $5.97^{\circ}$ incline, while participants from the control group walked on a horizontal pathway. Serum was collected from both groups preactivity (i.e. T1), immediately after activity (i.e. T2) and 24 hours after T1 (i.e. T3). The serum cartilage oligomeric matrix protein (COMP), chondroitin sulfate-WF6 (WF6) and hyaluronic acid (HA) levels at each time point were quantified using enzyme-linked immunosorbent assays, and the results analysed.

RESULTS Both groups shared similar demographic characteristics and activity duration. At T2, the serum COMP level of the experimental group was significantly higher than that of the control group, but the serum HA level of the experimental group was significantly lower than that of the control group. No significant difference between the serum WF6 levels of the experimental and control groups was observed at T2.

CONCLUSION Increasing levels of serum COMP demonstrate articular cartilage susceptibility to the increasing load. An unsustainable, high serum COMP level and an undetectable change in WF6 level were considered to be a reversible physiological change of the cartilage. A change in serum $\mathrm{HA}$ level could be related to intensive physical activity and dynamic clearance rather than a change in cartilage structure.

Keywords: biomarkers, cartilage, COMP, exercise, uphill walk

\section{INTRODUCTION}

The circulation pattern of cartilage biomarkers has been analysed in various pathological conditions, including osteoarthritis, rheumatoid arthritis and traumatic injury. The relationship between various degrees of load intensity in the physiological condition and the circulation pattern of biomarkers has also been addressed in order to determine the reliability of each biomarker. ${ }^{(1-3)}$ This is an important step in the validation process of biomarkers, prior to their use in clinical application. Furthermore, the sensitive relationship between minor changes in cartilage structure and serum biomarkers could be used for optimising activities to prevent long-term unfavourable consequences due to subclinical damage.

An inclined pathway is generally encountered in daily movements and favoured in recreational activities. It is frequently used by distance runners for muscle strength training and to improve their aerobic activity. However, knowledge regarding the consequences of uphill walking on articular cartilage is limited, and the circulation pattern of cartilage biomarkers in response to long-distance walks up an inclined pathway has never been studied. Biomechanical studies have reported that the joint reaction forces across the hip, knee and ankle joints were significantly increased during movement on an inclined pathway. ${ }^{(4,5)}$ The load when walking up an inclined pathway is larger than when walking on a horizontal pathway. This is because during a walk up an inclined pathway, there is a higher degree of joint moment and kinematic response, as substantially increased hip flexion and anterior pelvic tilt is needed to raise the body's centre of mass in a vertical direction to raise the foot. Knee dynamics display characteristics associated with raising and lowering the body weight, as well as the demand on ankles for a larger range of motion and strength. ${ }^{(4)}$

In this study, the circulation pattern of cartilage biomarkers due to a long-distance uphill walk was investigated. The study comprised two similar demographic groups that complied with either an uphill or horizontal walk under a fixed distance and duration, and a controlled degree of inclination. The circulation pattern of three potential biomarkers of cartilage serum cartilage oligomeric matrix protein (COMP), serum chondroitin sulfate-WF6 (WF6) and serum hyaluronic acid (HA) - were studied for a 24-hour duration, including pre- and post-activity.

\section{METHODS}

A total of 82 healthy individuals (experimental group $=58$, control group $=24$ ) participated in the present study. All participants were informed about the procedures in detail and their consent was obtained. The procedures were approved

${ }^{1}$ Department of Orthopaedics, Faculty of Medicine, ${ }^{2}$ Department of Physical Therapy, Faculty of Associated Medical Sciences, ${ }^{3}$ Thailand Excellence Centre for Tissue Engineering, Department of Biochemistry, Chiang Mai University, Chiang Mai, Thailand

Correspondence: Dr Dumnoensun Pruksakorn, Consultant, Department of Orthopaedics, Faculty of Medicine, Chiang Mai University, 239 Huay Kaew Road, Suthep, Muang, Chiang Mai 50200, Thailand. dumnoensun@hotmail.com 
by the Research Ethics Committee of the Faculty of Medicine, Chiang Mai University, Thailand. The inclusion criteria for the experimental group were: (a) age 18-25 years; (b) free from chronic disorders and diseases of the joints, bones, liver and endocrine system; and (c) ability to complete a $14-\mathrm{km}$ uphill walk. The participants in the control group were age-, body mass index- and gender-matched to their experimental counterparts. They had to be able to participate in a 14-km horizontal walk. Professional marathon runners and competitive athletes were excluded from the study.

Participants in the experimental group walked continuously for $14 \mathrm{~km}$ on a road with a known degree of inclination (average inclination angle: $5.97^{\circ}$, range $2.5^{\circ}-10.0^{\circ}$ ), while participants in the control group walked on a level road with a minimal degree of inclination (range $-0.5^{\circ}$ to $1.5^{\circ}$ ), termed as a 'horizontal walk'. Based on previous inclinable kinematic studies, joint loading at the hip, knee and ankle joints was predicted to be higher on the uphill walk than on the horizontal walk. ${ }^{(4,5)}$ The uphill walk was conducted a day before the horizontal walk, so that the average time spent during the horizontal walk could be controlled and made similar to the duration of the uphill walk.

All participants were advised to avoid any vigorous activities, including sports and running, two days before the experiment, and they were admitted into the research centre the night before the experimental date. A fasting morning serum was taken at 7:30-8:00 am after the participants had been awake for one hour (i.e. T1). The activity was started at 8:00 am, and the duration for both the experimental and control groups was limited to 200 mins. The second blood sample was taken within one hour after the activity ended (i.e. T2), and the third blood sample was taken at 8:00 am on the following day (i.e. T3), under the same conditions as the first sample collection. All samples were centrifuged at $6,500 \mathrm{~g}$ for $10 \mathrm{mins}$. The supernatants were stored at $-20^{\circ} \mathrm{C}$ until assayed.

Serum COMP was measured using a commercial enzymelinked immunosorbent assay (ELISA) kit (Human COMP ${ }^{\circledR}$ ELISA, AnaMar AB, Tyne and Wear, UK). Sequentially, $25 \mu \mathrm{L}$ of 1/10 diluted serum or standard COMP (0.4-3.2 U/L) and $100 \mu \mathrm{L}$ of enzyme conjugate were added into the microplate wells, which contained anti-COMP. The microplate was then incubated on a shaker for 2 hrs at room temperature. Detection of conjugated antibody was performed by adding $100 \mu \mathrm{L}$ of 3,3',5,5'-tetramethylbenzidine peroxidase substrate. The reaction was stopped after incubation for 15 mins by adding $20 \mu \mathrm{L}$ of $0.5 \mathrm{M}$ sulfuric acid. The absorbance was then measured at $450 \mathrm{~nm}$ using a microplate reader.

Serum WF6 was measured using competitive ELISA with a mAb-WF6 standard (i.e. shark cartilage aggrecan at a concentration of 19-10,000 ng/mL). The five-fold serum was diluted in $6 \% \mathrm{w} / \mathrm{v}$ bovine serum albumin (BSA) in Tris-EDTA buffer (0.1 M Tris-hydrochloride, $\mathrm{pH} 7.4$, containing $0.15 \mathrm{M}$ sodium chloride, $0.1 \%$ Tween 20 and $0.1 \%$ BSA), ${ }^{(6,7)}$ and an equal volume of WF6 (cell culture supernatant 1:200 dilution) was then added into a $1.5 \mathrm{~mL}$ plastic tube. These tubes were incubated at $37^{\circ} \mathrm{C}$ for $1 \mathrm{hr}$ before the samples were added into the microplate wells, which were pre-coated with the A1 fraction of the shark aggrecan. The plates were incubated at $37^{\circ} \mathrm{C}$ for $1 \mathrm{hr}$, after which the wells were washed and $100 \mu \mathrm{L}$ of peroxidase-conjugated anti-mouse IgM $(1: 2,000)$ was added into the wells. The bound conjugate was detected by adding $100 \mu \mathrm{L}$ of ortho-phenylenediamine. The reaction was stopped after 10 mins using $50 \mu \mathrm{L}$ of $4 \mathrm{M}$ sulfuric acid per well, and absorbance was determined at 492/690 nm using a microplate reader.

Serum HA was measured using ELISA-based assay for HA using biotinylated HA-binding proteins. Serum or standard HA (Healon ${ }^{\circledR}$ Advanced Medical Optics Uppsala Ab, Uppsala, Sweden) at $19-10,000 \mathrm{ng} / \mathrm{mL}$ in $6 \% \mathrm{w} / \mathrm{v}$ BSA in phosphate buffered saline $\mathrm{pH} 7.4$ was added to $1.5 \mathrm{~mL}$ plastic tubes containing biotinylated HA-binding proteins (1:200 in $0.05 \mathrm{M}$ Tris-hydrochloride buffer, $\mathrm{pH}$ 8.6). After the tubes were incubated at room temperature for $1 \mathrm{hr}$, the samples were added into the microplate wells, which were pre-coated with $100 \mathrm{mg} / \mathrm{mL}$ umbilical cord HA and blocked with 1\% BSA $(150 \mu \mathrm{L} /$ well). The microplate was then incubated at room temperature for $1 \mathrm{hr}$. After incubation, the wells were washed and $100 \mu \mathrm{L}$ of peroxidase-conjugated antibiotin antibody was added in each well. The microplate was then incubated at room temperature for another hour. Detection of conjugated antibody was done with ortho-phenylenediamine substrate.

All samples were measured in triplicate and the average of the three values were used for data analyses. The concentration of all serum biomarkers was calculated with reference to a standard curve. The identification data of the two groups was analysed using Student $t$-test and chi-square test for continuous variables and categorical variables, respectively. All quantitative data of serum COMP, WF6 and HA was analysed using a nonparametric Wilcoxon rank-sum test. Data was considered to be statistically significant if $p$-values were $<0.05$. All statistical analyses were performed using STATA software version 10.0 (StataCorp, College Station, TX, USA).

\section{RESULTS}

The participants in the control group $(n=24)$ and the experimental group $(\mathrm{n}=58)$ shared similar demographic characteristics and basic laboratory parameters, including age, gender ratio, body mass index, white blood cell count, and haemoglobin, serum creatinine, aspartate transaminase and alanine transaminase levels (Table I). The average walking durations of the control and experimental groups were $172 \pm 8$ mins and $174 \pm 25$ mins, respectively.

The biomarker levels measured are presented in Table II. While the serum COMP levels between T1 and T2, T2 and $\mathrm{T} 3$, and $\mathrm{T} 1$ and $\mathrm{T} 3$ were not significantly different in 
Table I. Identification data of patients $(n=82)$.

\begin{tabular}{|c|c|c|c|c|c|}
\hline \multirow[t]{2}{*}{ Variable } & \multicolumn{2}{|c|}{ Control group $(n=24)$} & \multicolumn{2}{|c|}{ Experimental group $(n=58)$} & \multirow[t]{2}{*}{ p-value } \\
\hline & Mean \pm SD & $95 \% \mathrm{Cl}$ & Mean \pm SD & $95 \% \mathrm{Cl}$ & \\
\hline Gender* & & & & & 0.45 \\
\hline Male & 8 & - & 24 & - & \\
\hline Female & 16 & - & 34 & - & \\
\hline Age $^{+}$(yrs) & $20(19-21)$ & $20.32-20.70$ & $20(19-21)$ & $20.22-20.54$ & 0.35 \\
\hline BMI $\left(\mathrm{kg} / \mathrm{m}^{2}\right)$ & $21.04 \pm 3.53$ & $19.55-22.53$ & $20.84 \pm 3.41$ & $19.94-21.74$ & 0.81 \\
\hline Haemoglobin $(\mathrm{g} / \mathrm{dL})$ & $14.26 \pm 1.69$ & $13.55-14.97$ & $14.34 \pm 1.83$ & $13.86-14.82$ & 0.85 \\
\hline WBC ( $10^{3}$ cells $\left./ \mu \mathrm{L}\right)$ & $8.21 \pm 1.27$ & $7.67-8.75$ & $8.54 \pm 1.14$ & $8.24-8.84$ & 0.25 \\
\hline Serum creatinine $(\mathrm{mg} / \mathrm{dL})$ & $0.81 \pm 0.08$ & $0.78-0.84$ & $0.83 \pm 0.09$ & $0.81-0.85$ & 0.35 \\
\hline Serum AST (IU/L) & $24.72 \pm 8.25$ & $21.24-28.20$ & $23.64 \pm 6.71$ & $21.88-25.40$ & 0.54 \\
\hline Serum ALT (IU/L) & $20.18 \pm 8.42$ & $16.62-23.74$ & $18.17 \pm 9.31$ & $15.72-20.62$ & 0.36 \\
\hline Duration (min) & $172.0 \pm 8.0$ & $168.6-175.3$ & $174.0 \pm 25.0$ & $167.4-180.6$ & 0.70 \\
\hline
\end{tabular}

${ }^{*}$ Data is presented as number. ${ }^{\dagger}$ Data is presented as median (range). ALT: alanine transaminase; AST: aspartate transaminase; BMI: body mass index; $\mathrm{CI}$ : confidence interval; SD: standard deviation; WBC: white blood cell

Table II. Comparison of serum biomarkers between the experimental and control groups.

\begin{tabular}{|c|c|c|c|c|c|}
\hline \multirow[t]{2}{*}{ Serum biomarker } & \multicolumn{2}{|c|}{ Control group $(n=24)$} & \multicolumn{2}{|c|}{ Experimental group $(n=58)$} & \multirow[t]{2}{*}{ p-value } \\
\hline & Median (SE) & $95 \% \mathrm{Cl}$ & Median (SE) & $95 \% \mathrm{Cl}$ & \\
\hline \multicolumn{6}{|l|}{ COMP (U/L) } \\
\hline $\mathrm{T} 1$ & $9.46(0.41)$ & $7.98-9.67$ & $9.68(0.38)$ & $9.27-10.80$ & 0.17 \\
\hline $\mathrm{T} 2$ & $10.07(0.53)$ & $8.11-10.30$ & $12.13(0.46)$ & $11.90-13.74$ & $<0.001^{*}$ \\
\hline T3 & $9.22(0.59)$ & $8.23-10.69$ & $7.99(0.31)$ & $7.64-8.88$ & 0.35 \\
\hline \multicolumn{6}{|l|}{ WF6 (ng/mL) } \\
\hline $\mathrm{T} 1$ & $289.15(35.00)$ & $255.46-400.28$ & $232.44(37.35)$ & $267.44-430.30$ & 0.49 \\
\hline $\mathrm{T} 2$ & $192.48(34.93)$ & $183.36-327.88$ & $260.56(25.15)$ & $224.17-326.19$ & 0.74 \\
\hline T3 & $204.87(38.01)$ & $203.59-361.13$ & $176.63(18.84)$ & $166.45-236.58$ & 0.17 \\
\hline \multicolumn{6}{|l|}{ HA (ng/mL) } \\
\hline $\mathrm{T} 1$ & 74.65 (8.03) & $63.98-97.21$ & $64.01(12.23)$ & $74.23-134.27$ & 0.55 \\
\hline $\mathrm{T} 2$ & $59.77(5.58)$ & $54.61-77.70$ & 31.89 (4.89) & $40.34-87.62$ & $0.005^{*}$ \\
\hline T3 & $91.56(8.03)$ & $73.56-106.76$ & $96.31(14.15)$ & $45.85-500.16$ & 0.54 \\
\hline
\end{tabular}

*Data is statistically significant. Cl: confidence interval; COMP: cartilage oligomeric matrix protein; HA: hyaluronic acid; SE: standard error; WF6: chondroitin sulfate-WF6

the control group, they were significantly different in the experimental group (Figs. 1a \& b). When the serum COMP levels of the control and experimental groups were compared at each time point, the serum COMP level at T2 was found to be significantly higher in the experimental group than in the control group (Fig. 1c). No significant differences were found for the other time points (i.e. T1 and T3).

Within the control group, the serum WF6 levels between $\mathrm{T} 1$ and $\mathrm{T} 2, \mathrm{~T} 2$ and $\mathrm{T} 3$, and $\mathrm{T} 1$ and $\mathrm{T} 3$ were not significantly different (Fig. 2a). However, within the experimental group a significant difference was detected between $\mathrm{T} 1$ and $\mathrm{T} 3$ (Fig. 2b). No significant difference was observed between the serum WF6 levels of the control and experimental groups at all time points (i.e. T1, T2 and T3) (Fig. 2c).

The serum HA levels between $\mathrm{T} 1$ and $\mathrm{T} 2, \mathrm{~T} 2$ and $\mathrm{T} 3$, and $\mathrm{T} 1$ and T3 within the control group were not significantly different (Fig 3a). In the experimental group, however, the serum HA levels between T2 and T3 was statistically significant (Fig. 3b). When the serum HA levels of the control and experimental groups were compared at each time point, the serum HA level at T2 was found to be significantly lower in the experimental group as compared to the control group
(Fig. 3c). No significant differences were found for the other time points (i.e. T1 and T3).

\section{DISCUSSION}

Some cartilage components are released into the synovial fluid and circulation when the articular cartilage is exposed to load. ${ }^{(8,9)}$ While the patterns of component release have been addressed in cartilage explanted models, the levels of cartilage components in circulation in response to physiological activity are unknown. ${ }^{(10-12)}$ Physiological susceptibility to load during an activity involving an inclined plane can be represented by comparing the serum biomarker levels of individuals walking on an inclined pathway with that of individuals walking on a horizontal pathway, under controlled variables. Changes in the dynamics of the lower limbs with respect to inclined angles have been described in a biomechanical study. ${ }^{(4)}$ Hip flexion, knee flexion and ankle dorsiflexion at heel strike increase when walking uphill. Greater joint moments and powers due to change in the angle of incline have also been reported. ${ }^{(4,5)}$ In order to maintain speed when moving up an inclined surface, Gottschall and $\mathrm{Kram}^{(13)}$ reported a significant increase in the propulsive ground reaction force during uphill locomotion, 


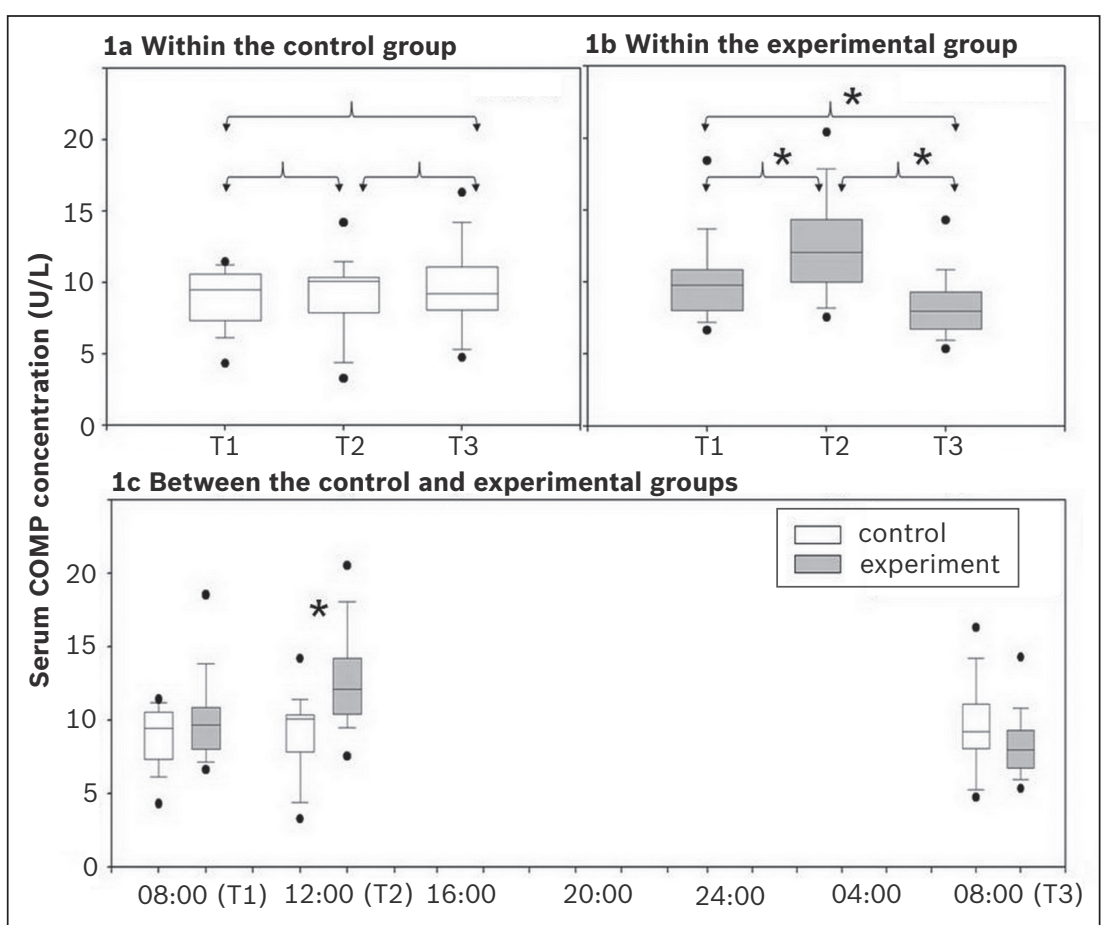

Fig. 1 Comparison of the serum cartilage oligomeric matrix protein levels at the different time points: (a) within the control group; (b) within the experimental group; and (c) between the control and experimental groups. An asterisk (*) indicates a statistically significant difference.

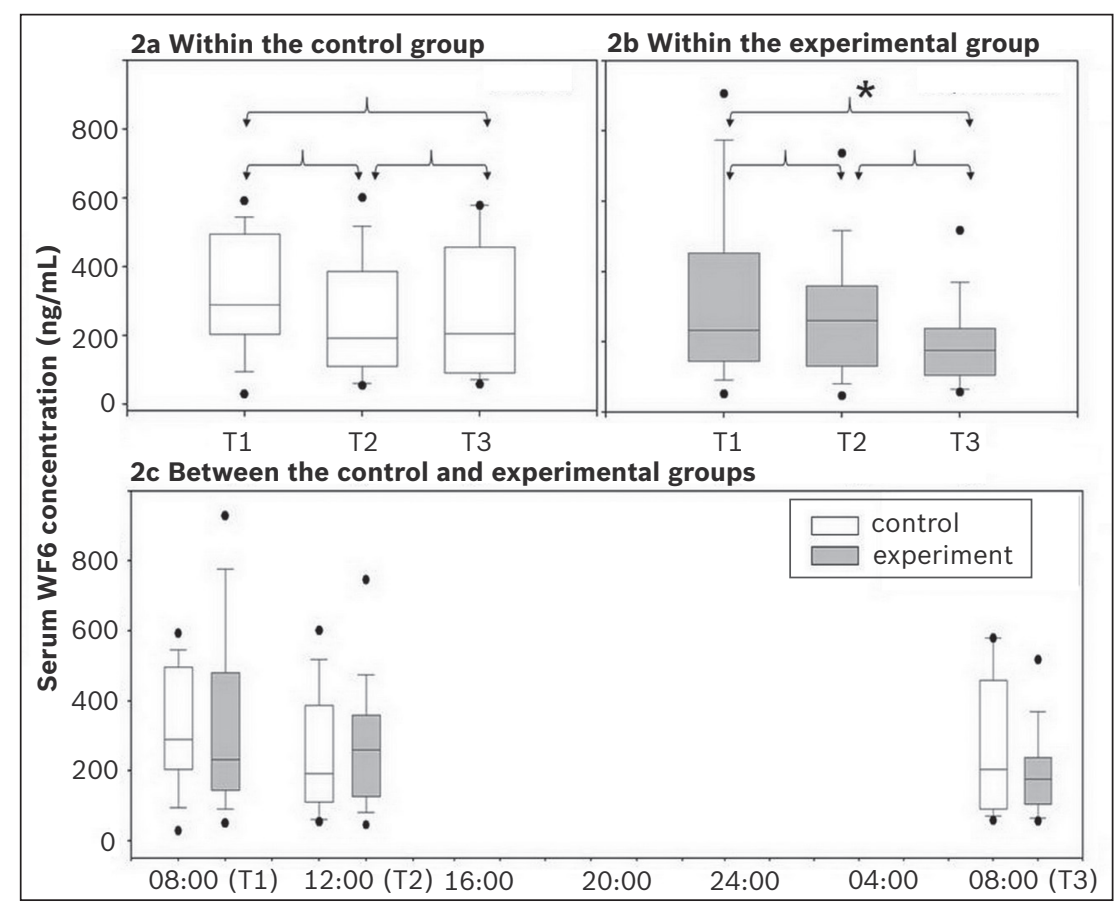

Fig. 2 Comparison of the serum chondroitin sulfate-WF6 levels at the different time points: (a) within the control group; (b) within the experimental group; and (c) between the control and experimental groups. An asterisk (*) indicates a statistically significant difference.

which would result in a greater shear force acting along the lower limb joint surface.

In our study, a higher circulating serum COMP level from baseline was detected immediately after both the horizontal and uphill walks (the increase was not significant for the horizontal walk), and the serum COMP level was significantly higher in participants who did the uphill walk than in those who did the horizontal walk. This increase in serum COMP level did not last for more than 24 hours after the activity. Serum COMP level is sensitive to the load that increases due to the body being raised in a vertical direction. Changes in serum COMP level was also reported in other hyperphysiological activities, including weight-bearing exercises, running and marathon running. ${ }^{(3,14,15)}$ The increase in COMP level was 


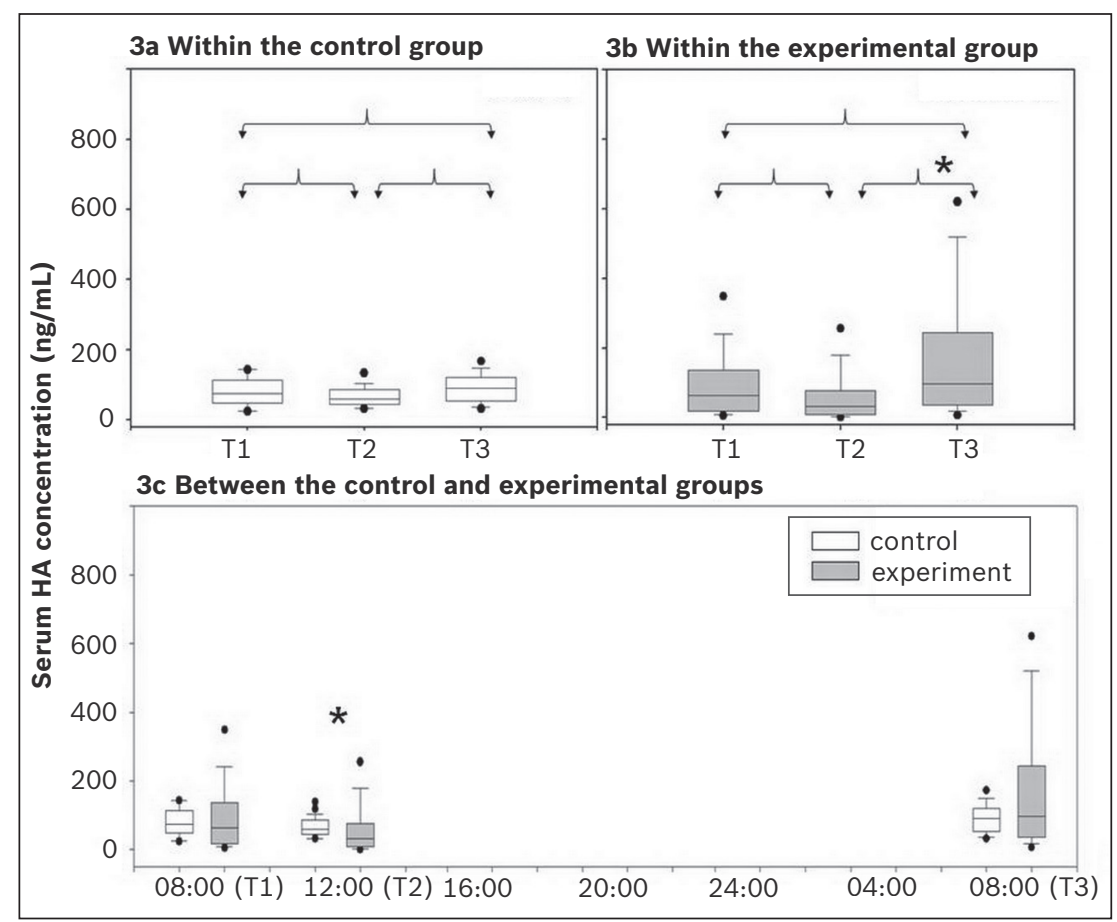

Fig. 3 Comparison of the serum hyaluronic acid levels at the different time points: (a) within the control group; (b) within the experimental group; and (c) between the control and experimental groups. An asterisk (*) indicates a statistically significant difference.

Table III. Studies comparing the susceptibility of serum cartilage oligomeric matrix protein levels to various loads and types of physical activity.

\begin{tabular}{|c|c|c|c|c|c|}
\hline Study, year & Type of activity & Population, age (yr) & $\begin{array}{l}\text { Intensity: } \\
\text { distance/ } \\
\text { duration }\end{array}$ & $\begin{array}{l}\text { Point increased marker } \\
\text { recorded (\% change } \\
\text { from baseline) }\end{array}$ & $\begin{array}{l}\text { Return to } \\
\text { baseline* (hr) }\end{array}$ \\
\hline $\begin{array}{l}\text { Neidhart et al, } \\
2000^{(15)}\end{array}$ & Marathon & Trained runners, 25-34 & $42 \mathrm{~km}$ & $\begin{array}{l}31 \mathrm{~km}(64) \\
42 \mathrm{~km}(76) \\
2 \mathrm{hrs}^{+}(82)\end{array}$ & 24 \\
\hline $\begin{array}{l}\text { Mündermann et al, } \\
2005^{(2)}\end{array}$ & Walk & Healthy, 26-37.8 & $30 \mathrm{~min}$ & IM (9.7) & $>6$ \\
\hline $\begin{array}{l}\text { Andersson et al, } \\
2006^{(1)}\end{array}$ & WB Ex & Osteoarthritis, 36-65 & $60 \mathrm{~min}$ & IM (10.5) & 0.5 \\
\hline $\begin{array}{l}\text { Kim et al, } \\
2009^{(3)}\end{array}$ & $\begin{array}{l}\text { Marathon } \\
\text { Ultramarathon }\end{array}$ & $\begin{array}{l}\text { Trained runners, 44-54 } \\
\text { Trained runners, 45-59 }\end{array}$ & $\begin{array}{l}42.2 \mathrm{~km} \\
200 \mathrm{~km}\end{array}$ & $\begin{array}{l}10 \text { km (60) } \\
\text { IM (90) }\end{array}$ & $\begin{array}{l}48 \\
144\end{array}$ \\
\hline $\begin{array}{l}\text { Mündermann et al, } \\
2009^{(14)}\end{array}$ & $\begin{array}{l}\text { Walk } \\
\text { Walk }\end{array}$ & $\begin{array}{l}\text { Healthy, 44-71 } \\
\text { Osteoarthritis, 40-74 }\end{array}$ & $\begin{array}{l}30 \mathrm{~min} \\
30 \mathrm{~min}\end{array}$ & $\begin{array}{l}\text { IM (5.6) } \\
\text { IM (6.3) }\end{array}$ & $\begin{array}{l}0.5-1.5 \\
0.5-1.5\end{array}$ \\
\hline Present study & $\begin{array}{l}\text { Uphill walk } \\
\text { Horizontal walk }\end{array}$ & $\begin{array}{l}\text { Healthy, } 19-21 \\
\text { Healthy, } 19-21\end{array}$ & $\begin{array}{l}14 \mathrm{~km} \\
14 \mathrm{~km}\end{array}$ & $\begin{array}{l}\text { IM (25.3) } \\
\text { NC }\end{array}$ & $\begin{array}{l}24 \\
-\end{array}$ \\
\hline
\end{tabular}

${ }^{*}$ Time measured from the start of the activity. ${ }^{\dagger}$ After completion of the marathon. ${ }^{\ddagger}$ Same study population as the Run group.

IM: immediately after activity; KB Ex: knee-bending exercise; LD Ex: lymphatic drainage exercise; NC: no significant change; WB Ex: weight-bearing exercise

usually detected immediately after the exercise protocol, with the highest detected level depending on the load intensity and duration of physical exposure. The time taken for the serum COMP level to return to baseline level after exposure to physiological activity was as follows: (a) within 30 mins after walking exercise; ${ }^{(2,14)}$ (b) up to 24 hours after marathon running (i.e. $42 \mathrm{~km}$ ); and (c) five days after ultramarathon running (i.e. $200 \mathrm{~km})^{(3,15)}$ Table III shows the comparative information of the specific physiological activities that affect serum COMP level. Sustained high serum COMP level was found in progressive extracellular matrix degradation due to impact injury or joint instability. Kühne et al found that serum COMP levels were significantly elevated in both early (less than two months after injury) and late (more than two months after injury) presentations of traumatic knee injury. ${ }^{(17)}$

Currently, there is scant literature regarding changes in proteoglycan levels (from either synovial fluid or serum) with 
regard to physiological and hyperphysiological activities. However, a significantly higher level of proteoglycan aggregan has been found in patients who have a pathological condition due to a traumatic knee injury; both Hazell et al ${ }^{(18)}$ and Lohmander et al ${ }^{(19)}$ found a significantly higher level of proteoglycan components in the synovial fluid of knees with anterior cruciate ligament $(\mathrm{ACL})$ injury than in normal contralateral knees. Pruksakorn et al reported sustained high serum WF6 levels in patients with ACL injuries when compared to healthy matched controls. ${ }^{(20)}$ In the present study, we did not detect any significant change in the level of circulating WF6 in response to an uphill walk. Presumably, the increased joint reaction force across the hip, knee and ankle from an uphill walk would cause a structural change in the collagen molecules, leading to a temporal increase in the serum COMP level. A transient high serum COMP level and an undetectable change in serum WF6 level were considered to be a reversible physiological change of articular cartilage that is susceptible to uphill walks.

$\mathrm{HA}$ is a high-molecular-weight glycosaminoglycan composed of extracellular matrix structure, and serum HA has been extensively studied as a biomarker for osteoarthritis. ${ }^{(21)}$ Increased serum HA level is an indicator of synovial inflammation and cartilage degradation. In the present study, serum HA had a similar pattern of change in both the control and experimental groups; the serum HA levels of both groups decreased immediately after the activity (i.e. T2) and returned to the baseline level 20 hours after the activity (i.e. T3). At T2, the serum HA level of the experimental group was significantly lower than that of the control group. This change in the serum HA level (i.e. a decrease) was opposite to the change observed in the serum COMP level (i.e. an increase). The temporary change in the level of serum HA depends on the pharmacokinetic change in HA level due to physiological response rather than cartilage structure change. ${ }^{(22-24)}$ The extravascular pool of HA from the lymphatic circulation can be rapidly transported into the circulation during exercise (enhanced during muscular contraction); it can also be transported into the circulation from the pulmonary lymph flow when induced by hyperventilation. ${ }^{(25)}$ A previous study reported that the magnitude of post-exercise serum HA clearance was proportional to the exercise-induced increase in serum HA, which is related to the level of exercise intensity. ${ }^{(26)}$ This was also demonstrated in the present study, where HA level was found to be susceptible to activities with a higher load intensity.

An optimal load provides nutrition and enhances metabolic homeostasis to cartilage tissue. It is also necessary for cartilage generation and healing. An increasing load on the weightbearing joint results in various degrees of subclinical change to articular cartilage. Based on the findings of the present study, the circulation pattern of serum biomarkers could have a possible role in the prediction of cartilage susceptibility to load during uphill walks; it could also be used to follow up on the subclinical changes of cartilage structure with further exploration. One limitation of the present study was the fact that the level of serum biomarkers was not monitored beyond 24 hours. This information could be an important contribution to the knowledge regarding serum biomarker susceptibility in uphill loading.

In conclusion, the uphill walk in this study resulted in an overall increase in the joint reaction forces across the articular cartilage of the weight-bearing joint. Serum COMP and HA were found to be sensitive for detecting changes in the intensity of the load, whereas there was no significant change in the serum WF6 level. The increased level of serum COMP could represent the susceptibility of articular cartilage to increasing load. An unsustainable, high serum COMP level and an undetectable change in serum WF6 level were considered to be a reversible physiological change of the articular cartilage. On the other hand, the change in the level of serum HA was related to intensive physical activity and dynamic clearance rather than change in cartilage structure.

\section{ACKNOWLEDGEMENTS}

The authors would like to express their deepest gratitude to Dr Prachya Kongtawelert, who provided substantial support to and advice on this project. This research was supported by grants from the Medical Research Fund of the Faculty of Medicine, Chiang Mai University, Thailand.

\section{REFERENCES}

1. Andersson $\mathrm{ML}$, Petersson IF, Karlsson $\mathrm{KE}$, et al. Diurnal variation in serum levels of cartilage oligomeric matrix protein in patients with knee osteoarthritis or rheumatoid arthritis. Ann Rheum Dis 2006; 65:1490-4.

2. Mündermann A, Dyrby CO, Andriacchi TP, King KB. Serum concentration of cartilage oligomeric matrix protein (COMP) is sensitive to physiological cyclic loading in healthy adults. Osteoarthritis Cartilage 2005; 13:34-8.

3. Kim HJ, Lee $\mathrm{YH}, \mathrm{Kim}$ CK. Changes in serum cartilage oligomeric matrix protein (COMP), plasma CPK and plasma hs-CRP in relation to running distance in a marathon $(42.195 \mathrm{~km})$ and an ultra-marathon $(200 \mathrm{~km})$ race. Eur J Appl Physiol 2009; 105:765-70.

4. McIntosh AS, Beatty KT, Dwan LN, Vickers DR. Gait dynamics on an inclined walkway. J Biomech 2006; 39:2491-502.

5. Yokozawa T, Fujii N, Ae M. Muscle activities of the lower limb during level and uphill running. J Biomech 2007; 40:3467-75.

6. Pothacharoen P, Siriaunkgul S, Ong-Chai S, et al. Raised serum chondroitin sulfate epitope level in ovarian epithelial cancer. J Biochem 2006; 140:517-24.

7. Pothacharoen P, Kalayanamitra K, Deepa SS, et al. Two related but distinct chondroitin sulfate mimetope octasaccharide sequences recognized by monoclonal antibody WF6. J Biol Chem 2007; 282:35232-46.

8. Quinn TM, Grodzinsky AJ, Hunziker EB, Sandy JD. Effects of injurious compression on matrix turnover around individual cells in calf articular cartilage explants. J Orthop Res 1998; 16:490-9.

9. Jeffrey JE, Thomson LA, Aspden RM. Matrix loss and synthesis following a single impact load on articular cartilage in vitro. Biochim Biophys Acta 1997; 1334:223-32.

10. Quinn TM, Allen RG, Schalet BJ, Perumbuli P, Hunziker EB. Matrix and cell injury due to sub-impact loading of adult bovine articular cartilage explants: effects of strain rate and peak stress. J Orthop Res 2001; 19:242-9.

11. Natoli RM, Scott CC, Athanasiou KA. Temporal effects of impact on articular cartilage cell death, gene expression, matrix biochemistry, and biomechanics. Ann Biomed Eng 2008; 36:780-92. 
12. Piscoya JL, Fermor B, Kraus VB, Stabler TV, Guilak F. The influence of mechanical compression on the induction of osteoarthritis-related biomarkers in articular cartilage explants. Osteoarthritis Cartilage 2005; 13:1092-9.

13. Gottschall JS, Kram R. Ground reaction forces during downhill and uphill running. J Biomech 2005; 38:445-52

14. Mündermann A, King KB, Smith RL, Andriacchi TP. Change in serum COMP concentration due to ambulatory load is not related to knee OA status. J Orthop Res 2009; 27:1408-13.

15. Neidhart M, Müller-Ladner U, Frey W, et al. Increased serum levels of non-collagenous matrix proteins (cartilage oligomeric matrix protein and melanoma inhibitory activity) in marathon runners. Osteoarthritis Cartilage 2000; 8:222-9.

16. Niehoff A, Kersting UG, Helling S, et al. Different mechanical loading protocols influence serum cartilage oligomeric matrix protein levels in young healthy humans. Eur J Appl Physiol 2010; 110:651-7.

17. Kühne SA, Neidhart M, Everson MP, et al. Persistent high serum levels of cartilage oligomeric matrix protein in a subgroup of patients with traumatic knee injury. Rheumatol Int 1998; 18:21-5.

18. Hazell PK, Dent C, Fairclough JA, Bayliss MT, Hardingham TE. Changes in glycosaminoglycan epitope levels in knee joint fluid following injury. Arthritis Rheum 1995; 38:953-9.

19. Lohmander LS, Dahlberg L, Ryd L, Heinegård D. Increased levels of proteoglycan fragments in knee joint fluid after injury. Arthritis Rheum 1989; 32:1434-42

20. Pruksakorn D, Rojanasthien S, Pothacharoen P, et al. Chondroitin sulfate epitope (WF6) and hyaluronic acid as serum markers of cartilage degeneration in patients following anterior cruciate ligament injury. J Sci Med Sport 2009; 12:445-8.

21. Inoue R, Ishibashi $Y$, Tsuda E, et al. Knee osteoarthritis, knee joint pain and aging in relation to increasing serum hyaluronan level in the Japanese population. Osteoarthritis Cartilage 2011; 19:51-7.

22. Sawka MN, Young AJ, Pandolf KB, Dennis RC, Valeri CR. Erythrocyte, plasma, and blood volume of healthy young men. Med Sci Sports Exerc 1992; 24:447-53.

23. Tulamo RM, Saari H, Konttinen YT. Determination of concentration of hyaluronate in equine serum. Am J Vet Res 1990; 51:740-2.

24. Rowell LB. Central circulator adjustment to dynamic exercise. New York: Oxford University Press, 1993.

25. Martin DJ, Grimbert FA, Baconnier P, Benchetrit G. Effect of acute hypoxia on lung transvascular filtration in anaesthetized dogs. Bull Eur Physiopathol Respir 1983; 19:7-11.

26. Hinghofer-Szalkay HG, Mekonen W, Rössler A, et al. Post-exercise decrease of plasma hyaluronan: increased clearance or diminished production? Physiol Res 2002; 51:139-44. 